$\begin{array}{ll} & \text { Etnográfica } \\ \text { etnográfica } & \text { Revista do Centro em Rede de Investigação em }\end{array}$

Antropologia

vol. $17(3) \mid 2013$

Vol. $17(3)$

\title{
Anna Fedele and Ruy Llera Blanes (orgs.), Encounters of Body and Soul in Contemporary Religious Practices: Anthropological Reflections
}

\section{Anastasios Panagiotopoulos}

\section{OpenEdition}

\section{Electronic version}

URL: https://journals.openedition.org/etnografica/3272

DOI: 10.4000/etnografica.3272

ISSN: 2182-2891

\section{Publisher}

Centro em Rede de Investigação em Antropologia

\section{Printed version}

Date of publication: 30 October 2013

Number of pages: 653-655

ISSN: 0873-6561

\section{Electronic reference}

Anastasios Panagiotopoulos, "Anna Fedele and Ruy Llera Blanes (orgs.), Encounters of Body and Soul in Contemporary Religious Practices: Anthropological Reflections", Etnográfica [Online], vol. 17 (3) | 2013, Online since 29 October 2013, connection on 11 February 2022. URL: http://journals.openedition.org/ etnografica/3272 ; DOI: https://doi.org/10.4000/etnografica.3272

\section{(c) (7) (8)}

Etnográfica is licensed under a Creative Commons Attribution-NonCommercial 4.0 International License. 
Anna Fedele and Ruy Llera Blanes (orgs.) ENCOUNTERS OF BODY AND SOUL IN CONTEMPORARY RELIGIOUS PRACTICES: ANTHROPOLOGICAL REFLECTIONS

New York, Berghahn Books, 2011 , 252 pages, ISBN: 978-0-85745-207-8.

The book places itself within a relatively recent effort in the social sciences to acknowledge the centrality of the body and the corporeal dimensions of social phenomena - in anthropology, see for instance, the works by Thomas Csordas (Embodiment and Experience, Cambridge University Press, 1994), Andrew Strathern and Michael Lambek (Bodies and Persons, Cambridge University Press, 1998), or Brian Turner (The Body and Society, Sage, 2008 [1984]). Religious contexts seem to be of particular interest because it is especially them that tend to be looked at through a Western and Christian lens, the editors argue in the introduction. This particular understanding is characterized by a clearcut division between the category of the body and that of the soul (spirit or mind). This division tends to subsequently privilege the soul part at the expense of the body. In other words, the understanding is based on a hierarchical opposition of pairs, a "classic binarism" (p. xii), reflecting a more general chain of oppositions (such as global/local, abstract/ /concrete, objective/subjective, theory/ /practice, among others). The explicit proposition of the book is to go beyond such binarism.

The collection of ten contributions, apart from one chapter which deals with witchcraft in the Central African Republic (ch. 6), is either from a traditionally Christian or Western context (in their great majority both); religious phenomena spreading all over Europe (Spain, Italy, Greece, Germany, the Netherlands and Denmark) and one chapter on Chile (ch. 2 ). The book is divided in three parts. The first refers to Catholic settings and how through the body apparently strict and dogmatic propositions that privilege the soul are highly relativized. The second part deals with human and consequently religious mobility and the way the body mediates, not only between abstract religious ideas and concrete experiences, but also between different cultural and ethnic understandings of them. The third part engages with "new spiritualities" that exist and even flourish (albeit not obviously) in a European and apparently Christian-dominated environment. The chapters of this part engage with ethnographic contexts in which the "official" Western/Christian divide between body and soul is consciously sought to be de-constructed, both conceptually and practically. All chapters are ethnographic cases wherein, according to their authors, the divide between soul and body 
and the subsequent privileging of the former against the latter is highly problematic.

The most important contribution of the book besides its explicit proclamation of going beyond the aforementioned binarism is that this occurs in ethnographic contexts where one would expect the binarism to flourish, that is, Christian and/or Western. Something that could have been shown in its fuller dimensions is whether these phenomena are marginal or not, sociologically speaking. If they are not, the whole understanding of a Western and/or Christian context is put into serious question, something that the whole book could have made more explicit and claimed as one of its founding contributions. Not only the hierarchical binarism between body and soul is proved not universal but they are seen as not absolutely Christian nor Western.

On this last point, there is generally a tendency to take for granted that the Christian and the Western context are more or less one and the same thing. Probably the most common intellectual shortcut used by scholars is that of the famous "Cartesian split, which often leads to false antinomies between the rational mind and the disorderly life of the body and the emotions" (ch. 6, p. 110). Here, I would like to express my scepticism when such an understanding is taken for granted. The whole book goes against this formulation as the context is indeed a Christian and Western one, yet the split is relativized, or else "mediated" following Engelke (p. xv) and the body and the soul are shown in their "codependence". Most importantly, the Cartesian split is problematic when one considers that in the same Western context there can be traced great variations in "understandings" and "worldviews", some of which stand even in conflict. For instance and here unavoidably over-generalizing, the differences between a secular or scientific vision of the world cannot be seen as one and the same context as a Christian vision.
Although there might be an underlying common background, there are also intense differences and disagreements.

As mentioned previously, the book wishes to go beyond the binarism between body and soul by shedding light to the "subaltern" category of the body. Each contribution does so successfully through interesting ethnographic accounts. One question that is initially raised is what, in terms of theory, comes after having shed enough of the missing light to the body? I suspect there is a danger lurking, namely, that of perpetuating the binarism, only now by privileging the previously subaltern category; that of the body in this case. Herein lies the main question for further discussion that this volume brings to mind. Apart from the very welcome indeed ethnographic proliferation of accounts on the active and creative role of the body in socio-cultural phenomena, where do we as a discipline stand as far as the body as a theoretical category is concerned? Let me use a long quote from the introduction here:

"The soul appears $[\ldots]$ as a slippery concept that can only be grasped focusing on its manifestations through the body. The different authors also emphasize the importance of lived, enacted religiosity and its difference from the official, institutionalized religion. Religion is lived and made visible through the body [...] In fact analysing the multiple meanings attributed to the body and the ways of coping with its limits in religious context allow anthropologists to do what in our opinion is one of the ultimate tasks of anthropology: grasping humanity beyond cultural and religious differences" (p. xxi).

This quote, I think, encapsulates not only the approach towards the body in the various contributions of the book but also the dominant one in anthropology; and perhaps all the social sciences. My question is, going beyond the ethnographic interest 
in the body, what is the novel conceptual mileage that we get out of it? One is definitely its centrality and the book clearly demonstrates this. But beyond its centrality, how far have we gotten into obtaining different understandings of it altogether? If the body acquires the role of transforming "slippery concepts", invisible, abstract, highly intellectual, spiritual or "soulful" issues into visible, "lived", "enacted" and concrete ones, then the body is not the site of difference but that of sameness and the universal (for an interesting discussion and effort to go beyond such and understanding of the body, see Eduardo Viveiros de Castro, "Cosmological deixis and Amerindian perspectivism", published in 1998 in the Journal of the Royal Anthropological Institute). This

Filomena Silvano (ensaio)

e João Pedro Rodrigues (documentários)

DE CASA EM CASA: SOBRE UM

ENCONTRO ENTRE ETNOGRAFIA

\section{E CINEMA}

Caldas da Rainha, Palavrão - Associa-

ção Cultural, 2012, 82 páginas + DVD, ISBN 978-989-97559-2-5.

Trata-se de uma edição de dois filmes e um texto. Portanto, um não vive sem o outro e só do encontro entre estas duas "peças" nasce o sentido do projeto. E o conceito de encontro é o que mais lhes convém, porque nem as imagens de João Pedro Rodrigues (JPR) partem das palavras de Filomena Silvano (FS) ou as usam, nem as palavras desta comentam as imagens daquele. A relação dá-se na total liberdade disciplinar does not sound very counter-intuitive to a Western ear but, on the contrary, as something too familiar. Therefore, I suspect that in order to gain new theoretical formulations of the body and the soul, what will also be welcome are accounts that not only go beyond their "great divide" but also the taken-for-granted understanding that one is the material and practical engagement of the other's inherently abstract and invisible nature.

\section{Anastasios Panagiotopoulos}

Centro em Rede de Investigação em Antropologia, Faculdade de Ciências Sociais e Humanas da Universidade Nova de Lisboa, Portugal anasta4@hotmail.com de cada uma das "peças" e no modo como, sem condescendências, cada um dos autores obedece às regras, princípios e formalismos do seu campo de atuação.

O texto de FS mostra que o exercício cinematográfico de JPR apresenta um conjunto forte de questões associadas à emigração e ao modo como no contexto da deslocação social, cultural e afetiva a identidade e a cultura se desenvolvem. Estes filmes permitiram à antropóloga encontrar o seu objeto de estudo: "Parece-me que ele [o filme do JPR] dá muito mais conta de algumas das minhas questóes do que as aproximações que os antropólogos lhes fazem. O filme não permite fazer uma leitura linear do espaço, mas consegue dar conta das minhas interrogações sobre o facto de a vida daquelas pessoas ser aquele permanente estar em trânsito. A opção do 